ESJ Humanities

\title{
Election Violence and Voter Turnout in 2019 General Elections: What Role for Political Parties?
}

\author{
Mustapha Salihu \\ Ph.D. Candidate, Conflict Peace \& Strategic Studies, \\ Nile University of Nigeria \\ Yahaya Yakubu \\ Nile University of Nigeria
}

Doi: $10.19044 /$ esj.2021.v17n2p137

Submitted: 05 November 2020

Accepted: 18 January 2021

Published: 31 January 2021
Copyright 2021 Author(s)

Under Creative Commons BY-NC-ND

4.0 OPEN ACCESS

Cite As:

Salihu M. \& Yakubu Y. (2021). Election Violence and Voter Turnout in 2019 General Elections: What Role for Political Parties?. European Scientific Journal, ESJ, 17(2), 137. https://doi.org/10.19044/esj.2021.v17n2p137

\begin{abstract}
This study examines the incidence of electoral violence and its resultant effects on voter turnout in the 2019 general elections in Nigeria, with the role of political parties as the focal point of discussion. A review of election data shows; voter turnout has been on the decline from $69 \%$ in 2003 to $35 \%$ in 2019. While a handful of factors could be responsible, the study ascribes its prevalence to the antic's political parties (incumbent and opposition) and politicians who deliberately deploy violence as an electoral strategy. To account for the relationship between, political parties, electoral violence and voter turn-out, the study builds on theories of voter mobilization in and advanced and emerging democracies. Against this, it concludes in the absence of enduring party-voter relations in Nigeria, political parties and politicians alike, resort to vote buying, mobilization of political thugs and in other times deployment of state coercive apparatus to intimidate opponents all of which culminates into electoral irregularities which has the potency to instigate electoral violence. This in turn has in amongst others adversely affected voter turn-out as rightly observed over five electoral cycles.
\end{abstract}

Keywords: Political Parties, Voter Mobilization, Electoral Violence, Voter Turnout and 2019 General Elections 


\section{Introduction}

Election violence are soon becoming reoccurring decimals in Nigeria's troubled electoral history. The deployment of violence as a strategy is sacrosanct to the conduct of election in Africa's most populous democracy. Predominantly, electoral violence in Nigeria is more than often perpetuated by political actors (politicians, political parties and voters), against opposition supporters, electoral officials, electoral observers, and civil society, media and security agencies. Similarly, violence can also be perpetuated by non-party elements or stakeholders that may have other ends. Nevertheless, it is a peculiar type of political violence, distinguished by its timing, targets and ultimately ends for which it is deployed (Hoglund et al, 2009). They are premedidated acts which includes but not limited to intimidation, discrimination and other forms of irregularities deployed with the aim of truncating electoral process or swaying electoral outcomes (Dexecker, 2019; John, 2019; Onapajo, 2014).

Dominant forms of electoral violence include intimidation, assassination, kidnapping, arson, ballot snatching and attacks on voting and collation with the aim of truncating electoral outcomes (John, 2019; Onapajo, 2014; Omotola 2010; Okoye, 2013). Survey-based evidence shows that, one in five Nigerians is exposed to electoral irregularities such as vote buying, and almost one in ten is exposed to electoral violence (Bratton, 2008). In addition, it is imperative to clarify that electoral violence goes beyond the eruption of violence during and after the particpatory act of voting, it can manifest at intra and inter party levels during conventions, campaigns and rallies. Owing to the multidimensional nature of electoral violence, the study limits its analysis to violent outbreak during and after the electoral act of voting.

Given the above discussion, the study examines the fondness for electoral violence in Nigeria, and its implications on voter turn-out. Focusing on the 2019 general elections, the study seeks to ascertain which parties (incumbent or opposition) deployed violence as a strategy, and attempt to theoretically establish a cause and effect relationship between political parties, electoral violence and voter turn-out. The proposition guiding the study states that;

I. More often than not, electoral violence are not spontaneous acts of violence, they are premeditated acts of violence deployed by political parties (incumbent and opposition) if it increases their chances at the polls. And that overtime, electoral violence has adversely affected voter turn-out in Nigeria's Fourth Republic.

\section{Methodology}

Materials for analysis are sourced from Afrobarometer (AB) database. $\mathrm{AB}$ is a non-partisan organization which publishes results of nationwide 
sample surveys on attitudes on citizens towards democracy, civil society, economy and other aspects of development in selected African countries. Specifically, time-series datasets from AB will cover the period 1999-2018, the data which will be analyzed using the $\mathrm{AB}$ online analysis tool, is done with a view to ascertain trends in party-voter relations. This is particularly important as it offers insight into the mechanism through which voters are mobilized in Nigeria. In addition, other secondary sources such as credible electoral reports of reputable observer missions (international and domestic), periodic and academic articles, and official publication from INEC will serve as main sources of literature. Although the neutrality of electoral observers has been subjected to criticism (Kelly, 2010), their reports remain the most reliable. Newspapers are susceptible and can be compromised. Nonetheless, some media reports in Nigeria have become increasingly popular.

\section{Theories of Voter Mobilization}

By virtue of party systems, political parties are central and compelling structures in the constitution of governments, more so with electoral democracies. They ordinate and control the human component, dictate the course of a public affairs and serve as intermediaries between the state and society (Ellanantranda, 2018; Adigwe, 1974). Political parties are important in many ways, however, it is important to highlight their utility in the electoral process, particularly,their role in informing voter preference at the ballot. In their capacities as institutionalized podia for political conscription and interest articulation, in ideal sense they assume the responsibility of purveyors through which the policy or ideological preferences of the voters find expression in governance (Animashaun, 2010; Chidi, 2015). Beyond fielding candidates, the significance and survival of a political party is sacrosanct on its ability to win elections.

In the context of consolidated democracies, Hagopain (2007) claims that, political parties either present themselves as competent administrators who share similar identity or ideology with voters or deploy other conventional means within the ambient of rule of law. Owing to institutionalization of partisan politics, voter mobilization is informed by sociological determinants (especially, socioeconomic) either organically (Lipset and Rokkan, 1967) or encouraged by party agency (Satori, 1969). Relatedly, Wren and Mcelwain (2009) claim, party organizational strategies play key roles in strengthening the relations between parties and voters.

In emerging democracies such as Nigeria, where political partisanship is thought to be vehemently weak, programme or ideology-based parties are momentary and party systems in exemplary terms barely exist. More than often, political parties and voters in Nigeria lack established long-term pacts which might inform voting behavior (Dalton and Klingemenn, 2009). In the 
absence of consistent party ideology, weak economic voter determinant, clearly defined programmes and manifestos, it is assumed that parties engage in the undemocratic act of vote buying, patronage or pork barrel projects for their communities (Hagopain, 2007, p. 583). In doing so, emerging democracies continue to be faced with the challenge of establishing a stable and institutionalized basis for party competition (Dalton et al, 2009). More than often, parties in emerging democracies engage in the commodification of elections, which obtains in vote peddling.

It is thought that many democracies in Africa are "patronage democracies" (Chandra, 2007). Under such institutional arrangements, resources are rarely redistributed transparently or equitably, but instead on partisan, ethnic, or other political lines. That the distribution of resources has been guided by patronage concerns, and ethnicity in particular, has long been assumed in the literature on African politics (e.g. Barkan and Chege, 1989) and recently a number of empirical studies have used new sources of data to validate these hypothesis (Franck and Rainer, 2012; Kramon and Posner, 2013). For Kramon (2013) politicians hand out cash because more often than not it conveys information to voters about their performance in the future, with emphasis on sustaining the patron-client relations. Put another way, he argues, cash for votes are effective because they affirm a politician's status as a dependable patron who can deliver resources to supporters even after the elections. The clientelism and patronage approach presupposes that patronage parties rarely establish formal links with voters, nonetheless they are assumed to have far more effects than program and ideology based parties (Hagopian, 2007; Lemerchand, 1971).

As rightly observed Cash handouts are extremely costly to political campaigns, encompassing a substantial fraction of campaign expenditures in Kenya and elsewhere. Taken that state and political party financing of political campaigns is minimal or non-existent, especially for local elections, political candidates often shoulder the bulk of the financial burden personally (Kramon, 2013). Many take out loans and go into substantial personal debt. It is therefore not surprising that the very politicians engaged in the distribution of money to voters are also those who complain about the system (Lindberg, 2003). The financial burden of cash hand out has been observed to foster corruption (Kramon, 2013), similarly politicians are more likely to protest their investments (votes) through rented muscle, political thugs, party agents or even state officials. Often than not, violence tends to erupt where votes are exchanged for cash handouts.

Findings of a study conducted by Bratton (2008) reveals that in the period leading to 2007 general elections, 12 percent of Nigerians interviewed confirm that party agents or candidates had offered "something" in return for votes. In the presence of financial or material inducement, the probability of 
political parties and their supporters to procure violence as a strategy, if it increases their chances of electoral success should not be altogether dismissed. Survey-based evidence shows that, one in five Nigerians is exposed to vote peddling, and almost four in ten is exposed to electoral violence (Bratton, 2008). Similarly, the results of AB time-series data Round 2 (R2) 2002/03, R3 2005/06, R4 2008/09, R5 2011/12, R6 2014/15 and R7 2017/18 which nationally representative shows that 38.4 percent of respondent claim party competition often leads to violence, 31.8 percent always and 5. 21 per cent never leads to violence respectively (Afrobarometer, 2020). The data overwhelmingly shows a significant proportion of Nigerians are convinced the antics of political parties and unhealthy nature of competition for voters leads to violence. While other studies such as that of Babayo et al (2018) have identified money or material benefits, religion and ethnicity as the strategies employed by parties to mobilise voters. The act of commodification the electoral act of voting, located within the larger practice of clientelism and patronage as obtains in Nigeria.

The absence of a universal framework underlying the dynamics of party/voters relations in emerging democracies, the study relies on empirical evidence from Afrobarometer Datasets. The Time Series Datasets collected over the period 1999-2018 seeks to ascertain if Nigerians felt close to political parties and if they attended any political campaign rallies. The results of the data analyzed will help address the issue of party-voters relations in Nigeria's Fourth Republic.

\begin{tabular}{|c|c|c|c|c|c|c|c|c|}
\hline \multirow{4}{*}{ Category } & \multicolumn{7}{|c|}{ Do you feel close to any Political Party? } & \multirow{3}{*}{$\begin{array}{l}\text { R7 } \\
2017 / 2018\end{array}$} \\
\hline & Total & $\begin{array}{l}\text { Round } \\
\text { R1 }\end{array}$ & $\mathbf{R 2}$ & R3 & R4 & R5 & R6 & \\
\hline & & $1999 / 2001$ & $2002 / 2003$ & $2005 / 2006$ & 2008/2009 & 2011/2012 & $2014 / 2015$ & \\
\hline & & $63.2 \%$ & $48.4 \%$ & $52.1 \%$ & $47.2 \%$ & $53.9 \%$ & $28.2 \%$ & $51.7 \%$ \\
\hline \multirow{2}{*}{$\begin{array}{l}\text { No, not close to } \\
\text { any party }\end{array}$} & $50.2 \%$ & & & & & & & \\
\hline & $48.8 \%$ & $36.8 \%$ & $49.6 \%$ & $46.8 \%$ & $50.8 \%$ & $45.6 \%$ & $70.4 \%$ & $48.2 \%$ \\
\hline $\begin{array}{l}\text { Yes, feels close } \\
\text { to a party }\end{array}$ & $1.0 \%$ & - & $1.9 \%$ & $1.1 \%$ & $2.0 \%$ & $0.5 \%$ & $1.4 \%$ & $0.1 \%$ \\
\hline $\begin{array}{l}\text { Don't know } \\
\text { (N) }\end{array}$ & $\begin{array}{r}16,662 \\
(100 \%)\end{array}$ & $\begin{array}{r}3,603 \\
(100 \%)\end{array}$ & $\begin{array}{r}2,365 \\
(100 \%)\end{array}$ & $\begin{array}{r}2,178 \\
(100 \%)\end{array}$ & $\begin{array}{r}2,242 \\
(100 \%)\end{array}$ & $\begin{array}{r}2,372 \\
(100 \%)\end{array}$ & $\begin{array}{r}2,319 \\
(100 \%)\end{array}$ & $\begin{array}{r}1,583 \\
(100 \%)\end{array}$ \\
\hline
\end{tabular}

Table 1 shows, of the 16,662 participants who were administered questionnaires over the period 1999-2018, 50.2 percent of the respondents claim they are not close to any political party, 48.8 percent feel close to a political party and 1.0 percent claim not to know. Based on insights from $A B$ datasets, it is evident that a little over half the population do not have ties with parties. However, the 48.8 percent who claim to have ties with political parties 
refutes the claims that parties in emerging democracies lack enduring partyvoter relations. It is also worthy to note that the datasets did not specify the nature of the closeness between parties-voters in Nigeria. However, there seems to be a consensus within the literature (INEC, 2019; Babayo et al, 2018; Okoye, 2013: Bratton, 2008) that party induce voters materially or invoke their ethnic consciousness. Hence, it is imperative to examine related datasets, which seek to ascertain the extent to which respondents participate in party functions (campaign rallies) as measure for gauging their closeness to political parties.

Thinking of the last National Elections, did you attend the Campaign Rally?

Round (R)

$\begin{array}{llll}\text { Category } & \text { Total } & \mathbf{R 5 ~ 2 0 1 1 / 2 0 1 2} & \mathbf{R 7 ~ 2 0 1 7 / 2 0 1 8} \\ \text { No } & 76.2 \% & 77.7 \% & 74.0 \% \\ \text { Yes } & 23.7 \% & 22.2 \% & 26.0 \% \\ \text { Don't know } & 0.1 \% & 0.1 \% & 0.0 \% \\ \text { (N) } & 4,000(100 \%) & 2,400(100 \%) & 1,600(100 \%)\end{array}$

Data Source; Afrobarometer, 2020.

AB R5 2011/12 and R7 2017/18 seeks to ascertain the degree to which respondents $\mathrm{N} 4000$, attended campaign rallies in the build up to the 2013 and 2019 general elections. Result shows a total of 76.2 percent did not attend, 23. 7 percent attended during the period under review. In contrast to table 1, table 2 measures active participant in parties activity (campaign rallies). The implication of data analyzed shows that; although a host of participants identify with political parties but they do not attend party functions. This results goes a long way in confirming theories (Hagopian, 2007; Lemerchand, 1971) which claims parties in emerging democracies lack enduring partyvoters relations.

Based on above empirical evidence, it will suffice to claim that while nearly half of the respondents surveyed claim to feel close to political parties, more than a third claim not to have attended campaign rallies which are avenues for voter conscription and interest articulation. The implications of above data is the affirmation of claims that political parties are more often than not involved in unconventional voter mobilization strategies such as vote buying and the use of violence to intimidate opposition.

\section{Trends in Electoral Violence and Voter Turnout Prior to 2019}

Nigeria's the Electoral Act 2010 (as amended) empowers political parties to hold conventions, either directly or indirectly, to enable them field candidates to compete for votes (European Union Electoral Observer Mission, 2019; PLAC, 2019). Section 229 of the 1999 constitution as amended, maintains that, "political parties' ' as formal organizations preoccupies itself 
with soliciting for votes during elections into various executive and legislative positions as designated in the constitution. As far as the electoral act of voting is concerned in Nigeria, it rests with the political parties and their aspirants to identify and deploy strategies that will increase their chances of success at the polls. The absence of constitutional backing for individual candidacy in Nigeria's electoral laws enforces the central role of political parties in the electoral process. Resultantly, the statutory act of voter mobilization remains a principal function of political parties and their supporters, though the mechanisms through which such function is pursued remains particularly relative. As immediate benefactors of electoral outcomes, the influence of political parties and their supporters in the electoral process is seemingly pronounced.

Given these high stakes of elections in Nigeria, politicians resort to a variety of means whether fair or foul to get public office (Bratton, 2008), if it is to increase their chances of electoral victories. The predisposition to appropriate and depend on violence as a strategy of electoral competition is partly attributed to the do-or-die nature of multi-party politics in Nigerian (Agbu, 2016: 92). As opposed to avenues for voter conscription and policy articulation, elections in Nigeria are usually keenly contested where the winner takes all as stipulated by the electoral laws (Animashaun, 2010: 14; Chidi, 2015).

In Nigeria, political actors are all too willing to exploit ethnic, religious, and ideological identities to perpetuate violence if it increases their chances of victory at the polls (Paul, 2019; International Crisis Group, 2018). In sum, multi-party democracy in Nigeria has been predominantly characterised by manipulations, maneuvering and re-alignment (Nwachukwu, 2015: 53). Impunity is endemic as perpetrators of electoral violence are hardly ever prosecuted. Electoral violence affects voter apathy. Systematic studies of the impact of electoral violence on electoral participation show a negative association between the two. A cross-sectional study revealed that voters who have experienced threats of election violence at the polls were less likely to vote in Nigeria (Bratton, 2013, p. 129). A cross-national study also found the same globally (Norris, 2014, p. 143).

Voter turnout represents the total number of persons who actively participate in the electoral act of voting. Blais (2007) proffered the individual and aggregate framework for measuring voter turnout. The former measures turnout by studying elections over a given period, while the latter is preoccupied with the descriptive question of who votes and why they vote? Hence, voter turnout is assumed to be relative to a number of factors ranging from conviction and trust in institutions to socio-economic determinants, they however can be located in prevailing political behaviour. The long term (1999 -2015) trends over five electoral cycles show that voter turnout has been in 
decline. The data reveals that voter turnout dropped from 30.2 million or $52.3 \%$ of registered voters in 1999 to 29.4 million or $43.7 \%$ of registered voters in 2015. Although there was a sharp increase in voter turnout in 2003, this declined again in 2007. The decline of voter turnout in 2007, could be attributed to widespread violence of 2003 general elections.

Violence during the 2003 election cycle was more flagrant and prevalent. Intra-party clashes, political assassinations, and civil unrest in already volatile areas such as Nigeria's oil-producing Niger Delta, characterized these elections. This cycle also marked the unchecked proliferation of another worrisome development: the recruitment and deployment of armed militias to serve narrow political ends. One concerned nongovernmental organization (NGO) monitoring the elections characterized them as "a low intensity armed struggle. Politicians and party bosses found a ready supply of unemployed men, frequently youths, willing to perpetrate violence in exchange for pay and firepower (Ebere et al., 2010). In 2003, 42 million voted as against the 60.8 million that registered (European Union Electoral Observer Mission, 2012; Centre for Democratic Development, 2018). Figures presented above represent the total number of eligible voters in the build-up to 2003 general elections and the actual number of vote casted.

The 2007 general elections saw the similar forms of violence and intimidation from earlier elections. In fact, by 2007, electoral violence had become such a credible risk despite Nigeria's return to democracy that the mere threat of it was enough to keep large swaths of voters away from the polls, as in Rivers state, where absentee ballot materials and violent threats contributed to low voter turnout (Ebere et al, 2010). In light of the violence unleashed during the 2007 and other past elections, Action- Aid Nigeria released a report in 2010 that classified Nigerian electoral violence squarely within the category of protracted social conflict, "characterized by civil strife, heightened social and political tension, and the sporadic use of violence, but in which armed conflict is not formally declared (Gbenro, 2010). In 2007, 61.6 million registered nationwide but 35.3 million voted (European Union Electoral Observer Mission, 2012; Centre for Democratic Development, 2018). Be it a coincidence or otherwise, the prevalence of violence in 2003 general elections was accompanied by low voter turn-out in the 2007 general elections. Keeping in mind the findings of two systematic studies of the impact of electoral violence on electoral participation show a negative association between the two. A cross-sectional study shows that voters who have experienced threats of election violence at the polls were less likely to vote in Nigeria (Bratton, 2013, p. 129). A cross-national study also found the same globally (Norris, 2014, p. 143).

The 2011 elections recorded one of the worst cases of election violence in the country. According to Human Right Watch (2012), 800 people were 
killed in deadly election-related violence in northern Nigeria. In 2011, a total 69.3 million people registered to vote but only 40.7 million voted. The post electoral violence in Kaduna state in 2011 was perpetrated predominantly by supporters of the opposition party (Congress for Progressive Change-CPC), supporting the claim that it is the weaker party that orchestrates violence. A close examination of the region in which electoral violence was more pronounced shows the rejection of voting outcome by supporters of the opposing CPC which has its stronghold in the north central states of Kaduna and Kano supports Collier and Vincente (2008) claim that weaker parties (opposition) facing electoral loss are more likely to resort to violence.

In 2015, a total number of 73.5 million people registered but only 29.7 million voted. Adjudged one of the most peaceful elections since the commencement of the Fourth Republic, the 2015 election saw the defeat of an incumbent. With the relative success achieved in the 2015 general elections, the Nigerian electorate was hopeful that a standard had been set, below which future elections should not fall (Civil Society Situation Room, 2019). . It is, however, important to stress that the keenly contested 2015 elections in which the opposition emerged victorious did not witness much violence. This has been partly credited to the incumbent President Goodluck Jonathan, who accepted the outcome of the election (CDD, 2018: 29).

The decline between 2011 and 2015 electoral cycles as earlier observed derives from, amongst other factors, the failure of INEC to prosecute perpetrators of electoral violence. For instance, in a study conducted by the Human Rights Monitor (HRM) on the prosecution and conviction of electoral offenders from January 2007 to March 2012 across 18 states, 294 cases were tracked out of which 24 have been tried, 78 struck out for incoherent prosecution and two electoral cycles later 181 cases are still in court (HRM, 2013). The accentuated fears of voters in the backdrop of institutional incapacity fed into voter apathy or poor turnout. Other security issues like the Boko Haram insurgency in the north east may have equally contributed to the decline in voter turnout (CDD, 2018: 14). It may therefore be argued that, amongst other structural factors, fear of violence has partly accounted for the consistent decline in voter turnout in Nigeria's Fourth Republic. As Sesan (2012) argued, electoral violence has a significant effect on citizen's participation in the political process. Beyond bearing the brunt of electoral violence, the persistence of violence negates the probability of guaranteeing citizens the right to representation, in instances where the fear of violent outbreaks deters eligible voters from casting their votes. Buttressing the above argument, INEC's Director for Voter Education, Festus Okoye claims electoral violence and malpractice is a muted issue, as the electoral umpire does not possess the capacity to prosecute electoral offenders as stipulated in the Electoral Act 2010 (Okoye, 2013). According to Adeniyi (2018), weak 
institutional capacity and inability to efficiently conduct and regulate elections have contributed to the prevalence of violence in Nigeria.

Against the backdrop of the foregone, it will suffice to claim that successive general elections (presidential elections) from 2003 to 2011 all witnessed widespread violence in both opposition and incumbent strongholds and they were characterized by a steady decline in voter turnout. In 2003, 42 million voted as against the 60.8 million that registered. In 2007, 61.6 million registered nationwide but 35.3 million voted. In 2011, a total 69.3 million people registered to vote but only 40.7 million voted. In 2015, a total number of 73.5 million people registered but only 29.7 million voted. (European Union Electoral Observer Mission, 2012; Centre for Democratic Development, 2018). Figures presented above represent the total number of eligible voters in the build-up to each election period, which points to the fact that while voter registration is in on the increase, the number of people who actually turn out to vote is declining.

\section{Electoral Violence and Voter Turnout During 2019 General Elections}

In the build-up to the 2019 general elections, about 80 million Nigerians registered to vote but the voter turnout was 34.75 per cent, the lowest since Nigeria's return to democracy in 1999 (ICIR, 2019). In 2019, INEC tracked a total of 482 electoral offenders across 36 states in Nigeria, out of which 167 were struck out for lacking merit, 24 persons convicted and 315 awaiting trial (INEC, 2019). According to Okoye (2013), most electoral offenders are also not prosecuted because INEC has less than 100 Legal Officers serving the Headquarters and the 36 State Offices including the Federal Capital Territory, Abuja and do not have the capacity and resources to prosecute offences committed in 119, 973 polling units, 8,809 wards, 360 Federal Constituencies, 109 Senatorial Districts and 774 Local Governments in Nigeria. In light of the available empirical evidence, it remains to be refuted that predisposition and violent antics of political actors over the years has not adversely affected turnout.

One of the perspective states that incumbent parties are the prime perpetrators of violence. Meyler (2007) in his study on electoral violence has argued that electoral violence are usually orchestrated by ruling parties, more so in multi-party states that do not meet minimum threshold for a democracy. While on the opposing end, Collier and Vincente (2008) argued that weaker parties (opposition) facing electoral loss are more likely to resort to violence as no violence shall manifest if the challenger was stronger. The evident decline in voter population between 2011 and 2015 election cycle can be attributed largely to the extant and deadly outcomes of post electoral violence that rocked the North part of Nigeria. 
While a myriad of factors can adversely affect voter turnout, civil society groups monitoring the 2019 general election under the auspices of Situation Room 2019 claim that postponing voting about six hours to the start of polls diminished the nationwide enthusiasm that had built up for the elections, taking that eligible voters who had journeyed to cast their vote in their constituencies to make a second trip, exacerbating voter apathy (Nigerian Civil Society Situation Room, 2019). It has also observed that the inability to prosecute electoral offenders over time may have informed the perpetration of election related violence during the 2019 general elections. Another factor that has affected voter turnout in the elections was the militarization of the electoral process in some parts of the country, particularly in the opposition stronghold of the south-south and North West respectively (Adeniyi, 2019).

During the 2019 general elections, INEC tracked a total of 482 electoral offenders across the 36 states, out of which 167 were struck out for lacking merit, 24 persons convicted and 315 awaiting trial (INEC, 2019). While the aforementioned data substantiates the prevalence of election violence in Nigeria, it fails to state specifically the perpetrators of such violence and its beneficiaries. In a report published by International Crisis Group (ICG) in 2018, lists of six states were put on electoral watch lists owing to the potential for violence to erupt in these states. They include Rivers, Akwa-Ibom (opposition stronghold), Kaduna (incumbent stronghold), Kano (incumbent stronghold), Plateau (undecided prior to election) and Adamawa (home state of opposition contender Atiku Abubakar of the PDP) respectively (International Crisis Group, 2018). During the election period, an estimated 626 persons were recorded to have lost their lives in the six-month period between the commencement of electoral campaigns and the electoral act of voting itself in election-related violence in 2019 (Nigerian Civil Society Situation Room, 2019). According to the report, the North Western region (an opposition stronghold) had the highest number of recorded deaths at 172, while the conflict-ridden North East followed with 146 fatalities. Furthermore, the South-South Region (opposition stronghold) recorded 120 fatalities while 111 were recorded in the North Central region (Kunle, 2019).

Upon review of aforementioned distribution of fatalities in the 2019 general elections shows that most fatalities were recorded in regions considered to be opposition strongholds on the basis that the opposition controls the state house of assembly and the government. Furthermore, the militarization of the South-South and institutional ineptitude on the side of the electoral umpire, INEC tends to support Meyler (2007) theory which claims that; electoral violence are often orchestrated by ruling parties, more so in multi-party states. Against this backdrop, therefore, it may be argued that, by deploying military personnel to opposition strongholds in the absence of civil 
unrest or insurgency, the incumbent APC employed coercive state apparatus to intimidate opposition voters.

\section{Conclusion}

Given the above discussion, it is fair to argue that the influence of political parties and their supporters on electoral violence and by extension voter turnout remains a dominant feature in Nigeria. Nonetheless, it is important to keep in mind the capacity of the average post-colonial state as well as the ability of the state to monopolize the legitimate use of force. The broad picture on the state of affairs in Nigeria can be located within the postcolonial theory and the inability to regulate the electoral process. It is against this backdrop that this study recommends strengthening of state institutions such as INEC, especially in the area of fiscal autonomy and independence from political actors. Any attempt at eradicating electoral violence, vote buying and other electoral malpractices will be insignificant if the socioeconomic plight of the average Nigerian is not elevated. In conclusion, there is a need for social reorientation of the Nigerian society at large, should elections be intended to serve as a media for policy articulation.

\section{References:}

1. Adeniyi, O. (2018). Foundation of Political Science, Ibadan: Ababa Press Limited.

2. Adenyi, T. O, Onyia, M. C and Nmanchi, K. C. (2019). Militarization, Electoral Violence and 2019 General Elections in Nigeria. International Journal of Social Sciences, Vol. 9. No. 10. Pp. 84-94.

3. Agbu, O. (2016). Elections and Governance in Nigeria's Fourth Republic . Dakar : CORDESIA.

4. Agbu, O. (2016b). Election Rigging and the use of Technology: The Smart Card Reader as the Joker in 2015 Presidential Election . Journal of African Elections, Vol. 15. No. 2. Pp. 90-110.

5. Animashaun, K. (2010). Regime Character, Electoral Crisis and the prospects of Electoral Reforms in Nigeria . Journal of Nigeria Studies , Vol. 1. No. 1. Pp. 1-33.

6. Babayo, S and Tal. M. K. (2018). Impact of Money on Nigerian Politics: Exploring the General Elections in the Fourth Republic . Asia Pacific Journal of Education, Arts \& Social Sciences, Vol. 5. No. 2. Pp. 89-98. .

7. Blais, A. (2007). Turnout in Elections . In K. Russel J and Hans-Dieter, Oxford Handbook of Political Behavior (pp. 621-635). Oxford : Oxford University Press. 
8. Policy and Legal Advocacy Centre. (2019). Electoral Act and INEC Guidelines Simplified. Abuja : Policy and Legal Advocacy Centre (PLAC).

9. Centre for Democracy and Development. (2018). Nigerian Electoral Trends. CDD, Abuja Nigeria.

10. Chidi, N. J. (2015). The Rise of the Opposition Political Party in Nigeria: Case Study of the All Progressive Congress. International Journal of Politics and Good Governance, Vol. VI. No. 6. Pp. 1-11.

11. Collier, P. (2010). War, Guns and Votes. Democracy in Dangerous Places . London : Vintage Books.

12. Dexecker, U. (2019). Unequal Votes, unequal violence: Malapportionment of Election Violence in India . Journal of Peace Research, XX. (X). Pp. 1-15.

13. Ejiofor, L. (2007). Politics and Mobilization: A Practical Handbook for Political Behavior. Abakiliki : Willy Rose \& Appleseed Publishing Coy.

14. European Union Electoral Observer Mission. (2019). General Election Guidelines: 23 February, 9 and 23 March . Abuja : European Union .

15. International Crisis Group. (2018). Nigeria's 2019 Elections: Six States to Watch . Brussels: International Crisis Group .

16. Hagopain, F. (2007). Parties and Voters in Emerging Democracies . In C. B. Stokes, The Oxford Handbook of Comparative Politics (pp. 582603). Oxford : Oxford University Press.

17. Hoglund, K. A and Pyarthine, A. (2009). Paying the Price for Patronage: Electoral Violence in Sri-Lanka. Common Wealth and Comparative Politics. Vol. 47. No. 3. Pp. 287-307.

18. Ikelegbe, A. (2013). Political Parties and Violence . Conference on Political Parties and the Future of Democracy in Nigeria (pp. 1-22). Kuru : National Institute for Policy and Strategic Studies \& Democracy and governance Development Project. (DGDO II of UNDP) 26-28 June.

19. International Centre for Investigative Reporting (ICIR) (2019). 2019 Election: Nigeria has the lowest rate of voter turnout in Africa https://www.icirnigeria.org/2019-election-nigeria- has-the-lowestvoter-turnout-in-africa/ (Accessed on 22 April 2010)

20. International Crisis Group. (2018). Nigeria's 2019 Elections: Six States to Watch. Brussels: International Crisis Group.

21. John, C. (2019). Tracking Electoral Violence in Nigeria. Council of Foreign Relations. February 15, 2019, Abuja Nigeria.

22. Kelly, J. (2010). Electoral Observers and their Biases. Journal of Democracy. Vol. 21. No. 3. Pp. 158-172. 
23. Mbah, O. P. (2019). Contentious Elections, Political Exclusion and Challenges of National Integration in Nigeria. Journal of Nigerian Studies. Vol. 5. Pp. 1-21.

24. Meyler, A. (20057). Party Systems and Voter Alignment: Cross National Perspectives. New York : Free Press

25. Nigerian Civil Society Situation Room. (2015). Reports on Nigeria's 2015 General Elections, March 28 and April 11, 2015. Policy and Legal Advocacy Centre, Abuja Nigeria.

26. Nigerian Civil Society Situation Room. (2019). Reports on Nigeria's 2019 General Elections, February 28 and April 11, 2019. Policy and Legal Advocacy Centre, Abuja Nigeria.

27. Nwankwo, J. C. (2015). Politics of Merger of Political Parties in Nigeria: The Past and Present Effort to Evolve Two Major PArties . Journal of Policy and Development Studies, Vol. 9. No. 2. Pp. 52-64.

28. Nwangwu, C and Mbah, O. P. (2016). Electoral Laws and Monitoring of Campaign Financing during the 2015 Presidential Elections in Nigeria. Japanese Journal of Political Science. Vol. 17. No. 4. Pp. 614-634.

29. Okoye, F. (2013). The Prosecution of Electoral Offenders in Nigeria: Challenges and Prospects. Abuja : Friedrich Ebert Stiftung .

30. Olowoju. O, Rasak, B, Ake, M, Ogundele, O and Afolayan, M. (2019). Trens in Electoral Violence in Nigeria . Journal of Social Science \& Public Policy, Vol. 11. No. 1. Pp. 37-52.

31. Onapajo, H. (2014). Violence and Voters in Nigeria: the Dominant use of Violence to Rig Votes. African Spectrum.Vol. 49. No. 2. Pp. 27-51.

32. Punch Editorial. (2019, February 16). Registered Voters: North West, South West Leads . Punch Online, p. 2.

33. Premium Times Editorial. (July 30, 2019). 626 Killed during 2019 General Elections in Nigeria - Report. Premium Times Online.

34. Vanguard Editorial. (2019, February 08). Governor el rufais 'bodybag' gaffe. Vanguard Newspaper Nigeria, p. 1.

35. Sari, S. M. (1967). Party Systems and Voter Alignment: Cross National Perspectives. New York : Free Press.

36. Satori, G. (1969). From the Sociology of Politics to Political Sociology . In S. M. Lipset, Politics and the Social Science (pp. 234-261). Oxford : Oxford University Press.

37. Sesan, O. (2012). Voter Apathy, Dangerous for Democracy. The Punch Newspaper. Septermber 27, 2012, Pp. 7.

38. Shamsudeen, K. B. (2015). Political and Electoral Violence in Nigeria: Mapping, Evolution and Patterns. IFRA Working Paper, Series No. 49. 